\title{
Review
}

\section{Illegal: How America's lawless immigration regime threatens us all}

\author{
Elizabeth F. Cohen \\ Basic Books, New York, 2020, 272 pp., \\ ISBN: 978-1541699847
}

Contemporary Political Theory (2021) 20, S131-S134. https://doi.org/10.1057/s41296020-00419-z; published online 17 July 2020

In her book, Illegal: How America's Lawless Immigration Regime Threatens Us $A l l$, Elizabeth Cohen has done a marvelous job of upending two of the main arguments in support of harsher and more expansive forms of immigration enforcement - the 'rule of law' argument and the 'social trust' argument. In doing so, she has lent significant intellectual firepower to the 'Abolish ICE' movement, which will hopefully be taken more seriously after the publication of this book.

The structure of the book can be thought of as having three parts, even though the author herself does not break it down in this way. The first part, comprising of chapters 1 and 2, focuses primarily on the first 'rule of law' argument for immigration enforcement. It shows how the agencies we have put in charge of enforcing our immigration laws, Immigration and Customs Enforcement (ICE) and Customs and Border Protection (CBP), and not undocumented immigrants, are the true threat to the rule of law, security, and liberty. These chapters outline the different ways in which these agencies have appealed to a state of exception in justifying their ever-expanding powers, ballooning budgets, and the lack of oversight and accountability. As the opening sentence of chapter 1 makes clear, this should worry us not simply because immigration enforcement has become an inefficient money pit — which it certainly has — but because it threatens everyone's rights and is based on bogus, often racist, justifications.

The opening chapter carefully outlines the threats ostensibly posed by undocumented immigrants and shows that they are based in fiction rather than fact. Undocumented immigrants are not a drain on our social safety nets, do not take jobs from US citizens, and are not more likely than average citizens-in fact they are less likely-to commit crime or pose a threat to the general public. Furthermore, the undocumented immigrant population in the US has declined since 2007, and the evidence suggests that this decline was not the result of increased immigration enforcement-whose diminishing returns are wonderfully graphed out in chapter 2-but to factors such as a downturn in the US economy and

(c) 2020 Springer Nature Limited. 1470-8914 Contemporary Political Theory Vol. 20, S3, S131-S134 
demographic shifts undergone in so-called sending countries such as Mexico. In fact, if there is any correlation between migration and immigration enforcement, it would seem to go in the opposite direction: increases in immigration enforcement tend to disrupt patterns of circular migration that in turn trap undocumented immigrants who otherwise would not have remained permanently. We therefore find ourselves in an immigration enforcement paradox: 'the need for enforcement is shrinking even as expenditures on enforcement are rising' (p. 13).

But why and how do we let this expansion of powers and budgets and the abuses committed by ICE and CBP continue? The second part of the book, comprising chapters 3 through 6 , answers this question. Chapters 3 and 4 carefully outline both the invention of the 'illegal' immigrant and the construction of a border that is in constant need of patrolling. At the start of chapter 3, Cohen helpfully reminds her readers that, odd as it might seem to us today, before the twentieth century, the federal government was not really involved in immigration. This job was left largely to state governments, which had no systematized process for deportation. With the rise of race-science and the eugenics movement at the end of the nineteenth century, this began to change. The federal government stepped in and began to pass racist immigration exclusions and quotas whose primary aim was to keep the US white. These laws were seen by many of its proponents as a natural corollary to the forced sterilization of black, indigenous, and people of color and anti-miscegenation laws that were in vogue at the time.

By 1924, federal immigration laws made certain, mostly non-white, foreigners ineligible for admission. As Cohen correctly points out, however, 'we cannot say [that this itself] made [their] immigration fully illegal because [these early laws] established no penalties or punishments for entering or being in the country in defiance of the quotas' (p. 101). The category of illegal immigrant still 'needed penalties to enforce, a documentation system to identify targets for enforcement, and enforcement personnel to do the work of penalizing and removing violators' ( $\mathrm{p}$. 101). These came with the creation of a federal border patrol and the corresponding bureaus of immigration and naturalization, whose sordid origin stories and the remaking of the US/Mexico border region are outlined in chapter 4.

Chapters 5 and 6 sketch the response to these early immigration laws. In chapter 5, Cohen points out that what US immigration policymakers in the $1920 \mathrm{~s}$ failed to anticipate was that 'their new prohibitions would starve the labor market [and] thus [attract] immigrants who were no whiter than the immigrants the quota had barred' (p. 125). This unintended consequence was the result of three key factors. First, early immigration restrictions were primarily focused on Asian immigrants and southern and eastern Europeans. Second, these policies left the border open to immigration from the entire Western hemisphere, so it was these immigrants who came to fill the void in the US labor market. Finally, American whiteness underwent a restructuring that in the nineteenth century would have been thought impossible. By the mid-twentieth century, southern and eastern Europeans

S132 (c) 2020 Springer Nature Limited. 1470-8914 Contemporary Political Theory Vol. 20, S3, S131-S134 
were no longer considered non-white, so there was pressure to lift restrictions on these immigrants.

The immigration reform act of 1965 attempted to account for these oversights, while also removing the last vestiges of overtly racist exclusions. As chapter 6 explains, this reform was not entirely successful because migration patterns to the United States had changed. Immigrants from southern and eastern Europe-who at this point were now considered fully white-were no longer coming in the same numbers as they had in the 1920s. Instead, there was an uptick in immigration from southeast Asia and Latin America. These changes in migration patterns, and the disavowal of openly racist exclusions, gave renewed and sustained life to what is often called the 'social trust' argument - the idea that there is something akin to an iron law of xenophobia in which increases in immigration, especially undocumented immigration, automatically lead to increases in anti-immigrant sentiment.

As Cohen repeatedly stresses, even during the most racist periods of US immigration history, there was always a statute of limitations provision that allowed undocumented immigrants to eventually regularize their status. This statute of limitations was part of the Registry Act of 1929, and due to its popularity, the date of registry was constantly updated. This is because undocumented immigrants who remained and made a life for themselves in the US were traditionally thought of as 'intentioners,' i.e., citizens-in-waiting, and not as perennial outlaws (p. 83). What this shows is that the connection we tend to draw between immigration and social distrust is not inevitable. Instead, it has been the outcome of a concerted effort by a coalition of elite conservatives and disaffected nativists. In chapter 6 , Cohen masterfully outlines the rise of contemporary nativist organizations in the USA, such as the Federation for American Immigration Reform (FAIR), the Center for Immigration Studies (CIS), and NumbersUSA, and their early attempts to greenwash their white supremacist agenda by casting their arguments as environmentally motivated and against overpopulation. Cohen connects these movements to current stereotypes of immigrants as drains on public resources, criminals, and terrorists. What her careful retelling of US immigration history makes clear is that the real threats to social trust-namely, authoritarianism and white supremacy_are not immigrants but harsher and more expansive forms of immigration enforcement.

The final part of the book provides the reader with an outline of what can be done, even in the current anti-immigrant climate. First, Cohen calls for an update of the registry date, which would reinstitute a statute of limitations for undocumented immigration. Far from requiring a major overhaul to the current system, this would only need an update to a law that has been on the books since the 1920s. Second, Cohen calls for the decriminalization of migration, or at least a return to pre-1996 conditions. As she points out in chapter 6, two laws passed in 1996 constitute a watershed in the treatment of undocumented immigrants-whose only crime is unlawful entry or stay, which is at worst a civil misdemeanor-as hardened

(c) 2020 Springer Nature Limited. 1470-8914 Contemporary Political Theory $\quad$ Vol. 20, S3, S131-S134 S133 
criminals. While repealing these laws and reintroducing a statute of limitations would, according to Cohen, reduce the number of targets for ICE and CBP, a third change is also necessary: to reorganize these agencies with an eye to stricter accountability, and a redirection of resources to hiring immigration judges and immigrant incorporation, rather than weapons and detention facilities.

While I could not agree more with Cohen's analysis, I worry about a tension that underlies her argument. In the introduction, she writes that, for people who know about the history of immigration to this country, 'the Trump era is not a shock. They already know that the United States is prone to nativism, sexism, and racism, and that among those who aren't nativist, sexist, and racist are people who prefer to believe myths about liberty and justice rather than see the country for what it is' (pp. 3-4). I strongly agree with this statement, but I am left wondering how to square it with a theme repeated throughout this book: that the expansion of immigration enforcement is inconsistent with the principles of US democracy. What if this is not an inconsistency at all, but a natural outcome of who we really are?

Publisher's Note Springer Nature remains neutral with regard to jurisdictional claims in published maps and institutional affiliations.

José Jorge Mendoza

University of Washington, Seattle, WA 98195, USA josejm@uw.edu 